\title{
Research on the Influencing Factors of Strategic Leadership Based on Lorentz Force
}

\author{
Linwei Yang \\ Wuhan University of Technology \\ Wuhan, China \\ walcjngu@163.com
}

\begin{abstract}
In the knowledge economy, the globalization develops unceasingly today. Strategic leadership, the embodiment of the strategic control ability of the enterprise, is closely related to the steady and rapid development of enterprises. Lacking of strategic leadership at the top of the enterprise has become a common phenomenon all over the word. And China is one of them. Based on the analogy of Lorentz force and strategic leadership in physics, this paper establishes the analogy logic of "strategic leadership - the physical force -Lorentz force". The influencing factors of strategic leadership are divided from a three-dimensional perspective "resource base, dynamic capability and competitive environment". And then, based on the physics formula of Lorentz force, the model of influence factor of strategic leadership is constructed, and the model is verified by regression analysis of data. By the analyzing the results, the conclusion is that resource base, dynamic capability and strategic leadership are positively correlated, and the competitive environment is negatively correlated with strategic leadership. According to the conclusion, the strategy of cultivating and improving strategic leadership can be used for enterprises as a reference.
\end{abstract}

Keywords-Strategic leadership; Enterprise dynamic ability; Resource base; Lorentz force

\section{INTRODUCTION}

Strategic leadership, the embodiment of the strategic control ability of the enterprise, is closely related to the steady and rapid development of enterprises. To maintain the competitive advantages in the global market, enterprises need strong strategic leadership strategic management regulation and control ability when facing the uncertainty and dynamics of the existing market environment. However, the lack of high-level strategic leadership has become a major problem hindering enterprises to improve their competitive advantage and reduce the cost of strategic management.

Taking the Lorentz force in physics as the starting point and the enterprise strategic leadership as the research object, this paper analyses the impact factors of strategic leadership based on three dimensions. The purpose of this paper is to find out the relationship between the three factors and the strategic leadership. And then a more applicable approach to the strategic leadership of the enterprise is suggested from a threedimensional perspective to help the enterprise build a culture, increase strategic leadership, and to provide new ideas for the factors that affect the strategic leadership of the enterprise.

\section{LITERATURE REVIEW}

Christensen (1997) proposed that strategic leadership is the ability of top leaders to make market forecasts, maintain organizational flexibility, and lead the organization in making long-term strategic decisions [1]. Peter and Quinn (2001) suggest that enterprises can improve their ability to survive by improving their strategic leadership, so as to ensure that enterprises are in good competitive advantage [2].

Bauer and Howie's proposed that learning ability, innovation ability and management wisdom embodied in the process of enterprise management are the key factors influencing the strategic leadership of enterprises [3]. Socek and other scholars have suggested the relationship between strategic leadership and resources base on the business process [4].

Huo Guo Qing (2009) points out that strategic leadership is the enterprise senior leaders in the comprehensive analysis of the stakeholders, enterprise itself. On the basis of strategic environment, he puts forward and carries out strategic target realization of a kind of ability, and defines the connotation of strategic leadership include vision, structural forces, path planning, balanced forces and endurance [5]. Ge Zun Feng (2011) suggests that strategic leadership is enhanced by strengthening enterprise learning ability [6].

The existing study of strategic leadership, are carried out from a single perspective, which lacks of environment, resource base, the comprehensive research of their capabilities. Therefore, this paper comprehensively considers the relationship between the three and the strategic leadership, and takes Lorentz force as the bridge, and constructs the influencing factor model to draw useful conclusions and values.

\section{RESEARCH DESIGN}

\section{A. Theoretical framework}

By constructing the correlation logic of "strategic leadership - physical force - Lorentz force", Lorentz force and strategic leadership are introduced to analyze the correlation. Lorentz force is the effect of the charge on the moving state after it enters the magnetic field, and then changes the current state of motion. The strategic leadership is applied to enterprises, and the enterprise combines its own resource base and dynamic capability to the environment, changing the state 
of competitive advantages and disadvantages. The changes of the particle or enterprise in the face of the surrounding environment make the change of state according to their own property. The correlation framework is shown in table I .

TABLE I. CORRELATION FRAMEWORK OF LORENTZ FORCE AND STRATEGIC LEADERSHIP

\begin{tabular}{|c|c|c|}
\hline Attribute & Lorentz force & strategic leadership \\
\hline $\begin{array}{c}\text { The external } \\
\text { environment }\end{array}$ & $\begin{array}{c}\text { magnetic field } \\
\text { environment }\end{array}$ & $\begin{array}{c}\text { Market competition } \\
\text { environment }\end{array}$ \\
\hline conditions & velocity & Dynamic capability \\
\hline
\end{tabular}

\section{B. Research hypothesis}

According to Lorentz force, the more charged particles are in the state of moving speed and magnetic field intensity, the greater the Lorentz force is. Thus a conclusion can be inferred that the stronger the corporate resources, the stronger the strategic leadership. Hypothesis 1: enterprise resource base is positively correlated with strategic leadership.

In the light of Lorentz force, the direction of Lorentz force in the magnetic field is determined by the direction of the magnetic induction and the velocity of the charge. It's a theory that the competitive environment determines the direction of strategic leadership, and the more volatile the environment, the more likely it is to represent a firm strategic leadership. So we can lead to the hypothesis 2: the more unstable the competitive environment is, the more it can reflect the strategic leadership of the enterprise.

Based on the nature of Lorentz theorem, in the same way that the magnetic field intensity and the amount of charge, the faster the charged particles, the stronger the Lorentz forces. The stronger the dynamic capability of the enterprise, the stronger the strategic leadership is. Hypothesis 3: dynamic capability is positively correlated with strategic leadership.

\section{Variable selection}

Based on the above research and hypothesis, the following variables are divided into the influencing factors of strategic leadership. By referring to the maturity scale of Lin Ping [7], Huo Guo Qing, Liu Jin and other scholars, we screened the indicators of influencing factors, selected variables and explained the following table. Explanatory variables are dynamic capabilities, enterprise resource bases and competitive environment. The explained variables are strategic leadership, and the questionnaire of influencing factors is designed according to the screening indicators. The variable description is shown in table II .
TABLE II. VARIABLE DESCRIPTION

\begin{tabular}{|c|c|c|l|}
\hline Variable types & $\begin{array}{c}\text { variable } \\
\text { name }\end{array}$ & symbol & \multicolumn{1}{|c|}{ interpret } \\
\hline \multirow{2}{*}{$\begin{array}{c}\text { Explanatory } \\
\text { variable }\end{array}$} & $\begin{array}{c}\text { dynamic } \\
\text { capability }\end{array}$ & DCP & $\begin{array}{l}\text { Organizational flexibility / } \\
\text { Learning ability } \\
\text { / Market orientation }\end{array}$ \\
\cline { 2 - 4 } & resource base & RBV & $\begin{array}{l}\text { Human resources / } \\
\text { Financial resources } \\
\text { / Creative ability }\end{array}$ \\
\cline { 2 - 4 } & $\begin{array}{c}\text { Market } \\
\text { competition } \\
\text { environment }\end{array}$ & $\mathrm{CE}$ & $\begin{array}{l}\text { Economy/ Political } \\
\text { environment/Market } \\
\text { barriers/Competitor/ } \\
\text { Environmental stability }\end{array}$ \\
\hline $\begin{array}{c}\text { explained } \\
\text { variables }\end{array}$ & $\begin{array}{c}\text { strategic } \\
\text { leadership }\end{array}$ & SL & $\begin{array}{l}\text { Strategic ideation / Strategic } \\
\text { decision-making ability } \\
\text { / Strategic planning ability } \\
\text { / Strategic implementation } \\
\text { capacity }\end{array}$ \\
\hline
\end{tabular}

D. Model construction

An influencing factors model of strategic leadership is constructed on the basis of the physical formula according to the correlation of above logic as well as the index selection, which is shown in "Fig 1":

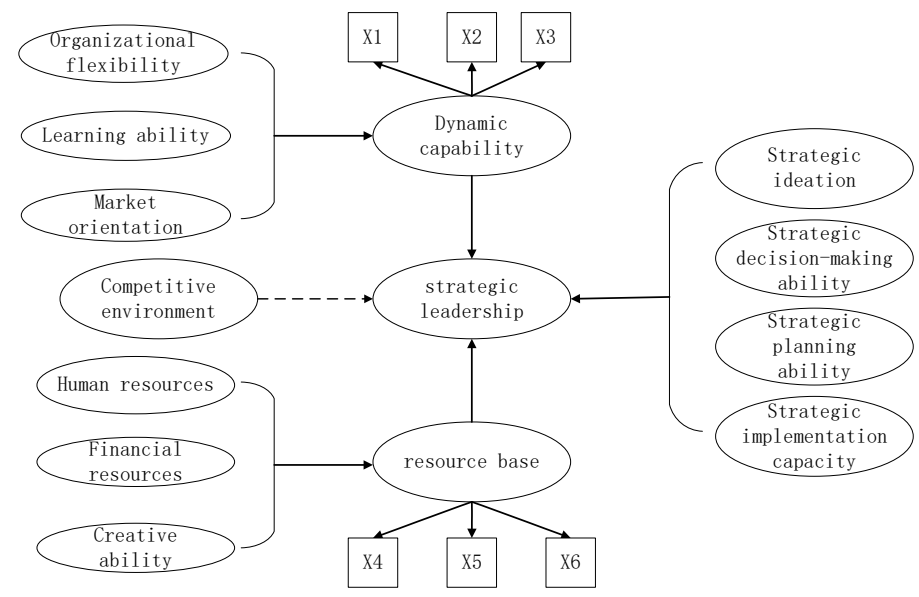

Fig. 1. Impact factors model of strategic leadership

Lorentz theorem formula:

$$
F=q \times v \times B
$$

Taking the logarithm of the above equation, we get the following formula:

$$
\ln F=\ln q+\ln v+\ln B
$$

The model of strategic leadership influencing factors is as follows:

$$
\ln S L_{i}=C_{i}+\beta_{1} \ln R B V_{i}+\beta_{2} \ln D C P_{i}+\beta_{3} \ln C E_{i}
$$

Where, i represents different enterprise samples, ci is constant, $\beta 1 、 \beta 2 、 \beta 3, \beta$ is the estimated parameter. $\mathrm{q}, \mathrm{v}$ and $B$ respectively represent the basis of enterprise resources, dynamic capabilities and competitive environment. 


\section{EMPIRICAL ANALYSIS}

\section{A. Data source}

In this study, the questionnaire was filled out by the middle and senior managers of various enterprises in the MBA class. The questionnaires were collected in 96 questionnaires, according to the standard of data collection. The incomplete and start-up questionnaire was eliminated, and 84 valid questionnaires were finally obtained. The effective rate was 87.5\%.

\section{B. Reliability and validity analysis}

The data is analyzed by SPSS software. Cronbach's Alpha coefficient is 0.945 , and the Alpha coefficient of resource base, dynamic capability and competitive environment is 0.828 , 0.880 and 0.805 respectively, which is greater than 0.7 . The data used in the scale is better than that of the data. According to the factor analysis of the data, the KMO value is 0.796 greater than 0.7 , and the spherical degree approximates chi square value is 349.298 , indicating that the overall validity is better, and the interpretation rate is $71.276 \%$.

\section{Regression analysis}

In this paper, the correlation test of specific indexes in questionnaire design and strategic leadership is presented in this paper. In the correlation test, the $P$ value of the 29 indicators of resource base, dynamic capability and competition environment is less than 0.05, which is the correlation between questionnaire index and strategic leadership. The correlation test results of resource base index and strategic leadership are shown in table III:

TABLE III. CORRELATION TEST OF RESOURCE BASE AND STRATEGIC LEADERSHIP

\begin{tabular}{|c|c|c|c|c|c|}
\hline & Staff size & sales & Debt ratio & $\begin{array}{c}\text { Intensity of } \\
\text { R\&D } \\
\text { investment }\end{array}$ & $\begin{array}{c}\text { R\&D } \\
\text { employee } \\
\text { proportion }\end{array}$ \\
\hline $\begin{array}{c}\text { Strategic } \\
\text { leadership }\end{array}$ & $.753^{* *}$ & $.756^{* *}$ & $.806^{* *}$ & $.653^{* *}$ & $.622^{* *}$ \\
\hline
\end{tabular}

Some dynamic ability indexes and strategic leadership correlation test results are shown in table IV:

TABLE IV. CORRELATION TEST OF DYNAMIC CAPABILITY AND STRATEGIC LEADERSHIP

\begin{tabular}{|c|c|c|c|c|c|}
\hline & $\begin{array}{c}\text { Channel } \\
\text { mining } \\
\text { information }\end{array}$ & $\begin{array}{c}\text { Spend } \\
\text { time } \\
\text { analysis }\end{array}$ & $\begin{array}{c}\text { Combination } \\
\text { of resources }\end{array}$ & $\begin{array}{c}\text { Respond to } \\
\text { customer } \\
\text { preferences }\end{array}$ & $\begin{array}{c}\text { Respond to } \\
\text { competitors }\end{array}$ \\
\hline $\begin{array}{c}\text { Strategic } \\
\text { leadership }\end{array}$ & $.644^{* *}$ & $.512 * *$ & $.382 * *$ & $.277 *$ & $.709 * *$ \\
\hline
\end{tabular}

After the correlation analysis of the above indicators, the correlation between indicators and strategic leadership was determined. To determine the relationship between the three and strategic leadership. First has carried on the simple to the three samples that peace process, the resource base, dynamic capabilities, the competitive environment of three-level index summation and logarithmic additive, after data processing, finally to multiple linear regression of strategic leadership. The regression results are shown in table $\mathrm{V}$, where the constant value is 0.584 , the coefficient of resource base is 0.410 , the dynamic ability coefficient is 0.602 , and the competitive environment coefficient is -0.163 . The resource base, dynamic capability and strategic leadership are positively correlated, namely, the stronger the two, the stronger the strategic leadership of the enterprise; the more unstable the competition environment, the more the enterprise strategic leadership can be embodied.

Strategic leadership model formula

$$
\ln S L i=0.584+0.410 \ln R B V+0.602 \ln D C P-0.163 \ln C E
$$

TABLE V. REGRESSION ANALYSIS RESULTS

\begin{tabular}{|c|c|c|c|c|c|}
\hline \multirow{2}{*}{ model } & \multicolumn{2}{|c|}{$\begin{array}{c}\text { Non-standardized } \\
\text { coefficient }\end{array}$} & $\begin{array}{c}\text { Standard } \\
\text { coefficient }\end{array}$ & \multirow{2}{*}{ Sig. } \\
\cline { 2 - 4 } & $\mathbf{B}$ & $\begin{array}{c}\text { Standard } \\
\text { error }\end{array}$ & Beta & & \\
\hline constant & .584 & .145 & & 4.025 & .000 \\
\hline resource base & .410 & .032 & .608 & 12.892 & .000 \\
\hline $\begin{array}{c}\text { dynamic } \\
\text { capability }\end{array}$ & .602 & .057 & .540 & 10.599 & .000 \\
\hline $\begin{array}{c}\text { Market } \\
\text { competition } \\
\text { environment }\end{array}$ & -.163 & .035 & -.175 & -4.632 & .000 \\
\hline
\end{tabular}

\section{CONCLUSIONS AND COUNTERMEASURES}

Based on the research conclusions, this paper concludes that the enterprise resource base, enterprise dynamic capability and the competitive environment of the enterprise jointly affect the strength of strategic leadership. This paper puts forward some countermeasures and Suggestions for cultivating and improving strategic leadership:

Enterprises should adjust the organizational form and improve the dynamic ability of the organization. They can take the way of combination of organization form and multiple organization ways, predesign temporary departments, or allow departments to flexibly adjust their working procedures and contents, and enhance the linkage effect among departments.

Enterprises should strengthen the strategic thinking of the senior managers and to improve the learning ability of middle managers. We should pay attention to the learning of managers' strategic theories and the cultivation of strategic logic. We should adjust the adaptability through summarizing typical cases or referring to the leading strategy of the industry.

Enterprises should improve the ability of enterprise strategic information collection and analysis. They can establish or improve existing information departments, employ professional data collection and analysis talents, update existing information communication equipment and information collection software, and improve enterprise information level. 


\section{ACKNOWLEDGMENT}

The authors acknowledge the financial support from the National Social Science Foundation of China (Grant No.15ZDC022, Grant No.17BGL209) and National Natural Science Foundation of China (Grant No.71373199).

\section{REFERENCES}

[1] Christensen C M. Making Strategy ; Learning by Doing[J].Harvard Business Review,1997,75 (6) ;141-156.
[2] Pctrick, J. A.g- J. F. Quinn, "The challenge of Leadership Accountability for Integrity Capacity as a Strategic Asset"[J].Journal of Business Ethics, 2001,24,331-343.

[3] Boal K B, Hooijberg R.Strategic leadership research: Moving on[J].The Leadership Quarterly, 2000,11(4):515-549.

[4] John J Sosik, Don I Jung ,Yair Berson ,et a1.Making All the right connections the strategic.leadership of top executives in high-tech organizations[J]. Organizational Dynamics, 2005, 34(1): 47-61

[5] Huo Guoqing, Miao Jianming, "Research on Strategic Leadership Model" Lead science, 2009,(04):4-7.

[6] Ge Zun Feng, "Research on the Influence of Strategic Leadership on the Dynamic Capabilities of Enterprises", Liaoning University, 2011.

[7] Lin Ping, "Research on the Dynamic Ability of Organization", Xiamen University,2008. 